\title{
PERAN GEREJA DALAM PENGEMBANGAN PROGRAM KEWIRAUSAHAAN DI ERA DIGITAL
}

\author{
Purnama Pasande ${ }^{1}$, Ezra Tari $^{2}$ \\ Sekolah Tinggi Teologi Star's Lub Luwuk Banggai ${ }^{1}$ \\ Sekolah Tinggi Agama Kristen Negeri Kupang ${ }^{2}$ \\ purnama.pasande@gmail.com ${ }^{1}$ \\ tariezra@gmail.com²
}

\begin{abstract}
In the digital era, the role of the church in developing entrepreneurial programs is facing new challenge thorough the application. Many entrepreneurship development models, for example, church located in a mall. There are also cooperatives within the church which selling snacks, many kinds of small and medium businesses, food stalls and others. The church is required to be creative in developing entrepreneurship, especially in this digital era. The research method used in this article is a qualitative research method with descriptive analysis. The research found entrepreneurial diversity, that showed dissimilar numerous things to another. Therefore, the Church must be active both in fulfilling spiritual and physical needs.
\end{abstract}

Keywords: entrepreneurship, church, digital era

Abstrak: Peran Gereja dalam mengembangkan program kewirausahaan dalam menghadapi era digital adalah mencoba tantangan baru melalui aplikasi. Banyak model pengembangan kewirausahaan misalnya, Gereja dengan mall satu lokasi. Ada juga koperasi, menjual makanan ringan, usaha kecil dan menengah, warung makan dan lain -lain. Gereja dituntut untuk kreatif dalam memngembangkan kewirausahaan, terutama di era digital ini. Metode penelitian yang digunakan dalam penulisan artikel ini adalah metode penelitian kualitatif. Di mana metode kualitatif bersifat deskriptif analisis. Peneliti menemukan keragaman kewirausahaan, sehingga tidak ada yang sama persis dengan yang lain. Karena itu, Gereja harus aktif baik dalam pemenuhan kebutuhan rohani maupun jasmani.

Kata kunci: kewirausahaan, gereja, era digital

Dalam pengamatan penulis perkambangan gereja di Indonesia sampai hari ini cukup signifikan. Di beberapa daerah ada pos pekabaran Injil atau gereja baru. Namun seiring perkembangan tersebut seringkali gereja melupakan tugasnya dalam memberdayakan ekonomi jemaat yang ada dalam gereja. Bahkan Gereja-Gereja sekarang ini umumnya hanya mengandalkan persembahan dari jemaat, seperti perpuluhan. Tetapi gereja tidak pernah gereja memikirkan bagaimana membangun ekonomi jemaat tersebut. 
Persoalan ekonomi menjadi salah satu yang menghambat perkembangan gereja baik secara kualitatif maupun kuantitatif. Jemaat bukan hanya membutuhkan spirit tetapi juga solusi atas persoalan yang dihadapi sehari-hari termasuk masalah keuangan, seperti pembayaran uang sekolah, listrik, kontrak rumah, dll. Pergumulan seperti ini riil di kalangan jemaat namun ironisnya, gereja sepertinya tidak mau tahu persoalan tersebut. Gereja seharusnya memberi edukasi kepada jemaat agar bisa mengembangkan dirinya dalam bidang kewirausahaan.

Dalam pengamatan penulis ada gereja yang belum mengembangkan kewirausahaan, misalnya Gereja Kristen Alkitab Indonesia Kadirojo Sampai hari ini masih belum ada program yang mengembangkan kewirausahaan di dalam gereja. Berbeda dengan Gereja Bethel Telios Indonesia Yogyakarta, saat ini sedang mengembangkan program kewirausahaan yakni Resto Joglo Harmoni yang berada di daerah Ngaklik Sleman. Ini merupakan respon atas panggilan sebagai orang percaya untuk mengembangkan kewirausahaan, yang di resmikan oleh bupati Sleman pada tanggal 15 Februari 2018. Mungkin saja pada tahap awal akan banyak tantangan dan bahkan mungkin kegagalan, namun dengan pantang berputus asa serta dengan tetap mengandalkan pertolongan Tuhan, niscaya gereja akan mampu menjawab kebutuhan yang ada (Andriono, 2017). Gereja masa kini yang semakin kaya akan realitas. Justru dengan teologi "tubuh" sekarang gereja ditantang untuk bergerak dalam hibriditas ruang publik, yang aktual dan virtual. Jean Nicolas Bazin dan Jerome Cottin melihat bahwa ada tiga cara terbaik untuk mendorong 
internet bermanfaat bagi gereja, yaitu sebagai alat informasi, sebagai alat berdialog dan bertukar komunikasi, dan sebagai alat untuk pencerahan (enlightenment) dan kehadiran (presence) gereja dalam dunia (Sianturi, 2014).

Dalam penelitian yang dilakukan oleh Hery Budiyanto, Agus Suprapto, Dina Poerwoningsih tentang program pengembangan kewirausahaan dalam bentuk inkubator bisnis di perguruan tinggi bagi mahasiswa pemilik usaha pemula. Mereka menemukan produk dari temuan yakni: Pertama, jasa atau produk Wira Usaha Baru (WUB) mahasiswa yang memiliki keunggulan ipteks, antara lain: produk kerajinan, makanan, jasa: persewaan sepeda motor. Dari 20 mahasiswa yang mengikuti kegiatan Inkubator Bisnis Mahasiswa, terdapat 8 mahasiswa yang telah mantap usahanya, sementara 12 mahasiswa masih melakukan rintisan usaha (Budiyanto, 2017).

\section{METODE}

Dalam menguraikan penelitian ini, penulis menggunakan metode penelitian kualitatif. Karena metode kualitatif bersifat deskriptif analisis (Tari, 2018). Talizaro Tafonao mengutip pendapat Sugiyono dalam buku metode penelitian manajemen mengatakan bahwa metode penelitian kualitatif adalah dapat diartikan sebagai metode penelitian yang digunakan untuk meneliti kondisi objek yang alamiah, di mana peneliti berperan sebagai instrument kunci, teknik pengumpulan data dilakukan secara trianggulasi (gabungan). Sumber data yang dipakai dalam penelitian kualitatif berupa lingkungan alamiah (Tafonao, 2019). 


\section{HASIL}

Salah satu contoh kewirausahaan yang bisa dilakukan gereja yakni usaha rumahan. Usaha yang dilakukan oleh masyarakat seperti bisnis rumahan ini justru lebih cepat berkembang. Bahkan disebutkan 53\% dari seluruh bisnis dijalankan di rumah, tetapi sekitar $80 \%$ diantaranya sangatlah kecil dan tanpa karyawan. Faktor yang menyebabkan banyaknya wirausahawan memilih rumah sebagai lokasi pilihan pertama adalah: 1) menjalankan bisnis dari rumah meminimalkan biaya awal dan operasi, 2) perusahaan bisnis dari rumah memungkinkan pemiliknya dapat mempertahankan gaya hidup dan gaya kerja fleksibel. Banyak wirausahawan bisnis di rumah menikmaati menjadi bagian dari angkatan kerja berkerahterbuka, 3) teknologi, yang mengubah banyak rumah-rumah biasanya menjadi "vila elektronik" memungkinkan wirausahawan dapat menjalankan berbagai macam bisnis di rumah mereka (Zimmerer, Scarborough, \& Wilson, 2008).

GMIM membentuk Balai Kerja dan Latihan Ketrerampilan memiliki 3 program utama yakni (1) membuka pendidikan bagi pemuda lulusan SMP sederajat, serta bagi pemuda-pemuda putus sekolah dalam hal program kerja kayu untuk produksi meubel, bangunan, souvenir. (2) Program pengolahan dan pemanfaatan kayu kelapa menjadi meubel, bangunan siap huni dengan konstruksi knock down, dan souvenir mulai pada tahun 1990; (3) Program pengolahan dan pemanfaatan kayu aren menjadi meubel, bahan bangunan, dan souvenir, mulai tahun 2008 (Sumbung, Suman, Kliwon, \& Paulus, 2012). 
Hasil peneltian lapangan yang dilakukan oleh Nababan bahwa untuk memberdayakan ekonomi kerakyatan yang berbasis jemaat adalah pertama, peran perguruan tinggi melalui lembaga penelitian. Di mana temuan dapat melihat potensi jemaat, potensi masyarakat, dan memberikan rekomendasi pada dimensi pertama dan kedua. kedua, kelompok mitra usaha, di mana terlibat lima kelompok yang merupakan satu kesatuan yang saling terkait dalam kegiatan usaha ekonomi. Ketiga, keterlibatan pemerintah dalam model pemberdayaan ekonomi jemaat dalam pembuat kebijakan dan pembinaan (Nababan, 2011).

Variabel sosial ekonomi seperti sikap positif masyarakat terhadap wirausaha, adanya keluarga maupun contoh wirausaha sukses, berbagai bidang usaha yang dapat dilakukan oleh wirausaha, serta pertumbuhan ekonomi yang relatif tinggi mampu mendorong pertumbuhan wirausaha. kebijakan dan prosedur pemerintah yang diharapkan berpengaruh positif dan signifikan terhadap pertumbuhan wirausaha, ternyata justru sebaliknya, oleh karena itu perlu dilakukan kajian khusus tentang kebijakan dan prosedur pemerintah, sehingga kebijakan dan prosedur yang dibuat pemerintah benar-benar sesuai dengan kebutuhan wirausaha. bantuan non keuangan secara parsial tidak berpengaruh terhadap pertumbuhan kewirausahaan, namun sebaik nya pemerintah dan lembaga pendidikan tetap menyelenggarakan bantuan non keuangan (Haryani, 2017).

Teknologi digital saat ini memberikan peluang seluas-luasnya untuk pelayanan dapat memberikan pengaruh yang tidak terbatas waktu dan ruang. Teknologi digital membuat dunia saat ini tidak lagi dapat dipisahkan antara dunia nyata dan dunia maya (Sitompul, 2017). Gereja 
harus fleksibel dan update, berupaya melakukan digitalisasi pelayanan, sehingga dapat menjawab sebuah kebutuhan rohani di sana (Hartono, 2018).

Di samping membuka penjualan online, peritel tradisional juga perlu mengintegrasikan toko online dan toko fisik dengan menerapkan bisnis online to offline $(\mathrm{O} 2 \mathrm{O})$. Lewat strategi ini peritel memberikan layanan yang memungkinan konsumen memesan barang secara online melalui website dan melakukan pembayaran dan pengambilan barang di toko secara langsung (DBS, 2017).

Stedzer menawarkan tiga hal terkait bagaimana Gereja dapat memanfaatkan teknologi digital ini dalam memenuhi panggilan ekklesiologis-misionalnya, antara lain: Pertama, Technology Enables Communication: meelalui sosial media seperti Facebook dan Twitter atau melalui Blog Gereja, Kedua, Technology Enables Community: teknologi memungkinkan ikatan komunitas eklesiologis yang lebih besar yang tidak menuntut kedekatan secara fisik. Ketiga, Technology Enables Discipleship: gunakan teknologi di gereja untuk memungkinkan komunikasi, dan pemuridan. Gereja digital dapat saja menciptakan dan memiliki sebuah aplikasi khusus di mana jemaat dapat mengakses secara bebas seperti: baik outline khotbah, materi pelajaran alkitab berseri, diskusi isu-isu terkini hingga menjadi media pengumuman mingguan gerejawi, melalui telpon pintar masing-masing (Afandi, 2018). Aspek kewirausahaan adalah pertama, aspek transparency memegang pengaruh yang dominan pada entrepreneurial university dalam 
memengaruhi sikap kognitif masyarakat dibandingkan dengan aspek sustainability dan accountability. Melalui implementasi transparency mampu meningkatkan persepsi positif masyarakat pada nilai universitas sebagai perguruan tinggi berkarakter entrepreneurship. Kedua, aspek sustainability mempunyai pengaruh yang dominan pada entrepreneurial university programme dalam memengaruhi sikap afektif masyarakat.

Implementasi sustainability pada pelaksanaan program pelatihan kewirausahaan mampu meningkatkan motivasi dan kesadaran para masyarakat untuk menerapkan entrepreneur mindset dalam diri para komunitas. Meningkatnya motivasi dan kesadaran para masyarakat dapat meningkatkan nilai universitas ciputra sebagai entrepreneurial university yang mampu membangun karakter entrepreneurship pada masyarakat. Ketiga, aspek transparency juga mempunyai pengaruh paling dominan dalam sikap konatif para penerima program. Dengan demikian munculnya rasa bangga penerima program dalam aktivitas yang dilaksanakan Universitas Ciputra akan meningkatkan keberanian dan komitmen para penerima program untuk berwirausaha. Secara tidak langsung hal ini menyebabkan reputasi Universitas Ciputra sebagai lembaga pendidikan memiliki kepedulian yang besar akan pendidikan kewirausahaan kepada masyarakat luas (Rini, 2016).

Kuatnya kepemimpinan suatu lembaga akan mempengaruhi keunggulan lembaga itu sendiri. Kekuatan kepemimpinan menghasilkan berbagai kebijakan dan operasionalisasi kerja yang dibimbing oleh visi dan misi yang akan dijadikan dasar pencapaian tujuan. Visi yang dijalankan secara konsisten harus menuntut perubahan budaya yang lebih ber- 
orientasi pada mutu baik proses maupun hasil (Rizky, 2018).

Jalan kemaslahatan dapat dilakukan dengan mengambil sikap teguh yakni: pertama, peran directing, pentingnya redefinsi bahwa kepentingan revolusi industri adalah sebagai kepentingan mempermudah keinginan (wants) manusia dalam memenuhi kebutuhannya (needs). Kedua, peran transferring, perubahan sistem masyarakat menjadi masyarakat terbuka serta berubahnya tatanan dunia baru menuju era globalisasi menyebabkan berubahnya paradigma pembangunan pada negara. Ketiga, peran transforming, pelaksanaan peran transformasi didasarkan pada asumsi bahwa setiap revolusi diasumsikan mempunyai muatan nilai positif yang bermanfaat bagi kehidupan bersama baik pada konteks pemeritahan (goverment) atau masyarakat (civil society). Keempat, peran transcending, peran ini dapat terwujud manakala terdapat keyaninan terhadap kebenaran hakiki (Suwardana, 2017).

\section{PEMBAHASAN}

Gereja terus berkembang dari abad ke abad, terutama dari segi pertumbuhan penginjilan. Namun demikian, perhatian gereja pada pengembangan program kewirausahaan minim. Belum banyak gereja yang melakukan itu. Perpuluhan jemaat masih menjadi andalan utama sebagai sumber pemasukan untuk membiayai pelayanan gereja.

\section{Dasar Teologis}

Secara teologis kewirausahaan merupakan salah satu usaha yang dikehendaki Tuhan. Ini memiliki landasan yang kuat dalam Alkitab. 
Dalam Mazmur 23, gembala diingatkan untuk menuntun dombanya ke rumput yang hijau dan air yang tenang. Yesus sendiri juga mengatakan "Mintalah, maka akan diberikan kepadamu; carilah, maka kamu akan mendapat; ketoklah, maka pintu akan dibukakan bagimu" (Mat. 7:7). Rasul paulus memberikan contoh dalam pelayanannya. Sambil pelayanan ia juga menjalankan profesi sebagai tukang tenda (Kis18:3). Selain Rasul Paulus, dalam Alkitab ada beberapa tokoh yang juga sukses dalam menjalankan kewirausahaan. Di antaranya adalah Abraham (Kej. 13, 14, 19, 21). Salomo (1 Raj 5, 9). dan Lydia dari Tiatira IKis 16:14-15, 40).

Untuk itu gereja perlu didorong mengembangkan potensi kreativitas dan inovasinya dalam mengubah tantangan yang dihadapi untuk menjadi peluang. Jemaat tidak hanya memiliki kemampuan memberikan persembahan tetapi jemaat dapat diberdayakan memiliki kemampuan berwirausaha. Dorongan kewirausahaan perlu dilakukan oleh pemimpin-pemimpin Kristen, khususnya pemimpin Gereja di mana seorang gembala melayani.

Jalan yang ditempuh untuk melakukan perubahan adalah 1) peran directing. Pentingnya redefinsi bahwa kepentingan revolusi industri adalah sebagai kepentingan mempermudah keinginan (wants) manusia dalam memenuhi kebutuhannya (needs). 2) peran transfering. Terjadi pergeseran fungsi birokrasi (reinventing the government) di mana pemerintah yang tadinya menjadi pelaku utama pembangunan (provider) berubah fungsinya menjadi fasilitator pembangunan (enabler) atau yang 
disebut dengan pemerintahan katalis. 3) peran transforming. Pelaksanaan peran transformasi didasarkan pada asumsi bahwa setiap revolusi diasumsikan mempunyai muatan nilai positif yang bermanfaat bagi kehidupan bersama baik pada konteks pemeritahan (goverment) atau masyarakat (civil society). 4) peran transcending. Peran ini dapat terwujud manakala terdapat keyaninan terhadap kebenaran hakiki (Suwardana, 2017).

Proses pengembangan kewirausahaan memilki empat tahap yang berbeda: 1) Identifikasi dan evaluasi peluang 2) Pengembangan rencana bisnis 3) Penetapan sumber daya yang dibutuhkan 4) Manajemen perusahaan yang dihasilkan (Rosmiati, Junias, \& Munawar, 2015).

\section{Praktik Kewirausahaan Gereja}

Koperasi gereja

Gereja Masehi Injili di Timor (GMIT) Kupang mengembangkan kewirausahaan di bidang koperasi. Gereja Toraja khususnya klasis Makassar juga mengembangkan koperasi. Koperasi itu bertujuan pengembangan ekonomi jemaat.

\section{Usaha Gereja Kristen Protestan Bali (GKPB)}

Sebagaimana dipaparkan Julianto (2017), Gereja Kristen Protestan Bali telah memiliki sejumlah usaha yang dikelola oleh 2 yayasan, yaitu Yayasan Dhyana Pura dan Yayasan Maha Bhoga Marga (MBM). 
Usaha di bawah Yayasan Dhyana Pura antara lain:

- Hotel Resort Dhyana Pura.

- Sekolah Perhotelan dan Pariwisata PPLP dan STIM: Menyediakan pendidikan perhotelan dan kepariwisataan bagi warga jemaat dan masyarakat dengan biaya pendidikan yang lebih murah;

- Wisma Nangun Kerti: Tempat pusat meditasi atau tempat retreat di pegunungan khususnya bagi anak-anak muda dan juga di area taman di rancang sebagai tempat doa dan meditasi karena telah didirikan sebuah kapel disitu;

- Jasa Penyelenggaraan Pernikahan Asing: untuk memfasilitasi jasa tersebut disediakan sebuah Kapel, Kapel ini di gunakan secara khusus untuk tempat penyelenggaraan pernikahan internasional dan pada hari minggu digunakan untuk ibadah bagi jemaat yang bertempat tinggal di kawasan Seminyak.

Yayasan Maha Bhoga Marga sendiri mengelola kegiatan usaha berikut:

- Pembinaan dan pelatihan kerja serta pengembangan masyarakat dalam bidang ketrampilan-ketrampilan;

- Usaha Permebelan;

- Bank Pengkreditan Rakyat dan Pinjaman Modal Sarana Usaha;

- Usaha Percetakan.

\section{Usaha Gereja Kristen Jawa (GKJ)}

Selain GKPB, Julianto (2017) juga memaparkan usaha yang dilakukan oleh Gereja Kristen Jawa (GKJ). Usaha-usaha tersebut antara lain:

- Dana Abadi Sinode GKJ

Ini adalah program Penggalangan Dana Besi untuk kemandirian, yang muncul di kalangan Sinode, cq. Deputat Penatalayanan. Tujuannya untuk: 
$\diamond$ Peningkatan kapitalisasi Dana Pensiun GKJ.

$\diamond$ Membantu jemaat-jemaat yang tidak mampu memanggil Pendeta.

$\diamond$ Dana batuan Biaya Hidup Tenaga GKJ.

$\diamond$ Perkreditan perumahan tenaga gereja, biaya studi anak peserta Dana Pensiun GKJ.

$\diamond$ Biaya studi lanjut, peningkatan kemampuan pendeta, dan lainlain.

- PT. Rumeksa Mekaring Sabda

Inilah bentuk usaha Sinode GKJ yang bertugas murni untuk mencari keuntungan. PT ini adalah keberlanjutan PT Perperin yang bertugas mengelola lahan seluas 90 hektar di Salatiga, yang terkenal dengan sebutan Kawasan Salib Putih.

- Unit-Unit Usaha yang dikelola oleh Kantor Sinode GKJ

Unit usaha yang dikelola oleh Kantor Sinode GKJ di luar struktur yang dibentuk oleh Bapelsin sebagai kepanjangtanganan Sidang Sinode:

$\diamond$ Wisma Kasih: Wisma penginapan yang didesain sebagai bagian dari fasilitas umum Sinode GKJ, dapat menampung 89 orang dengan harga yang terjangkau masyarakat.

$\checkmark$ Menyewakan beberapa fasilitas umum pertahun, beberapa ruang disewa oleh Gereja-Gereja baru.

$\diamond$ Toko Buku "Taman Pustaka Kristen”:

$\diamond$ Angkringan ing Sinode: Unit usaha baru Kantor Sinode GKJ yaitu menjual makanan dan minum berbasis kenyamanan.

$\diamond$ Koperasi Simpan Pinjam "Dana Daya”: Sebagaimana koperasi yang lain, maka koperasi ini dibentuk untuk mewadahi kebutuhan dana para pendeta, pegawai gereja dan gereja-gereja sesinode GKJ. 


\section{Usaha Gereja Kristen Jawi Wetan (GKJW) Jemaat Tunglur}

Gereja Kristen Jawi Wetan (GKJW) Jemaat Tunglur juga memiliki usaha. Buono (2017) menyebutkan 2 antaranya:

- Kafe Door

Gereja menyediakan sarana berupa bangunan fisik, para pemuda lantas melakukan aktivitas latihan wirausaha di sana. .... mendukung program-program kepemudaan di jemaat. .... sebelum mereka terjun ke dunia kerja, mereka telah mengenal bagaimana kulakan, bagaimana bertemu dengan pelanggan, bagaimana berpromosi, bagaiman menyajikan sesuatu dengan baik, bagaimana menentukan harga barang, bagaimana membaca selera pasar lokal, bagaimana menghadapi stress dalam pekerjaan, bagaimana menghadapi keuntungan dan kerugian, dan terutama bagaimana tetap menjaga nilai Kristen dalam wirausaha yang mereka lakukan (Buono, 2017, p. 13).

- Kelas Kreatif

.... untuk anak dan remaja... untuk melatih anak-anak membuat kreativitas, mulai dari kerajinan tangan, memasak, membersihkan lingkungan gereja, menjaga kesehatan, berbagi, hingga beberapa kali membazarkan hasilnya dengan pendampingan pamong anak dan remaja sebagai latihan awal bagi anak dan remaja berlatih wirausaha (Buono, 2017, p. 13)..

Mencermati contoh-contoh kewirausahaan di atas maka gereja dapat menjadikan contoh untuk membuat kewirausahaan yang sama atau merumuskan kewirausahaan yang baru. Di mana era digital telah menjadi kebutuhan manusia modern saat ini.

Jika ingin merencanakan wirausaha, beberapa kiat yang dapat diperoleh dari materi ajar kewirausahaan dideskripsikan sebagai berikut:

1. Halaman pembuka / judul memberikan ringkasan singkat dari isi rencana bisnis, berisi :

$\checkmark \quad$ Nama dan alamat perusahaan

$\diamond \quad$ Nama pengusaha, data nomor telpon, alamat dsb. 
$\diamond \quad$ Satu paragraf deskripsi perusahaan dan sifat bisnisnya, jumlah pembeayaan yang dibutuhkan, bisa dalam bentuk paket.

$\diamond \quad$ Pernyataan kerahasiaan bahan ini.

2. Ringkasan Eksekutif. Bagian yang penting, mencoba meyakinkan investor bahwa dokumen ini layak untuk di baca. Biasanya berisi :

$\diamond \quad$ Apakah konsep dan model bisnis

$\diamond \quad$ Apa yang unik dari bisnis ini

$\diamond \quad$ Siapa individu-individu yang memulai bisnis ini.

$\diamond \quad$ Bagaimnana bisnis menghasilkan uang dan berapa banyak (Harjono, 2011-2012).

3. Analisis lingkungan dan industri. Adalah penilaian variabel-variabel tak terkendali eksternal yang mungkin mempengaruhi rencana bisnis, Yang termasuk Environtmental Analisys :

$\diamond \quad$ Ekonomi (GDB)

$\diamond \quad$ Kultur

$\diamond \quad$ Teknologi

$\diamond \quad$ Persoalan hukum Termasuk Analisis Industri: Permintaan industri Kompetisi.

$\diamond \quad$ Pokok-pokok penting untuk analis lingkungan dan industri.

4. Deskripsi Perusahaan. Memberikan tinjauan lengkap mengenai Produk, jasa dan operasi-operasi perusahaan baru. Dari deskripsi ini memungkian investor mengetahui ukuran dan lingkup bisnis. Dimulai visi dan misi statement.

5. Rencana produksi.

6. Rencana Operasi.

7. Rencana pemasaran.

8. Rencana Organisasional. Mendsekripsikan bentuk kepemilikan serta garis otoritas dan tanggung.

9. Penilaian Resiko. Mengidentifikasikan bahaya potensial dan strategi -strategi alternatif untuk mencapai sasaran -sasaran dan tujuantujuan rencana bisnis (Harjono, 2011). 
Program lain yang bisa dibuat adalah seri pelatihan untuk memberikan pengetahuan dan keterampilan dasar terkait keuangan dan kewirausahaan bagi para individu yang ingin membangun sebuah usaha. Peserta dari seri pelatihan tersebut menjadi subjek penelitian untuk melihat gambaran pengetahuan tentang keuangan dan kewirausahaan yang dimiliki oleh calon wirausahawan dan evaluasi diri yang terjadi selama sesi pelatihan berlangsung. Hasil penelitian memperlihatkan bahwa pengetahuan dasar terkait manajemen keuangan dan kewirausahaan yang dimiliki individu calon wirausahawan di Indonesia masih rendah, khususnya terkait peluang bisnis dan rencana bisnis. Latar belakang pendidikan subjek yang berkisar antara ahli madya (diploma) dan sarjana tidak menghasilkan gambaran yang berbeda terkait pengetahuan mereka (Marbun \& Kaihatu, 2016).

Karena itu, Yakob Tomatala menyatakan bahwa, entrepreneur atau wirausaha rohani (Kristen) adalah orang yang memiliki hubungan unik dengan Tuhan sebagai dasar kekuatan dan integritasnya dalam berusaha. Entrepreneur rohani (Kristen) adalah penyalur berkat Tuhan kepada orang lain yang ada disekitarnya (Tomatala, 2010).

Sutoyo mengutip pendapat Mastra (2009) mengenai kewirausahaan mengatakan bahwa:

Pengembangan ekonomi gereja Bali dengan mempraktikkan Usaha-Usaha Bisnis Gereja di bawah Yayasan seperti Resor Dhyana Pura, Sekolah Perhotelan dan Pariwisata PPLP dan STIM, Wisma, Nangun Kerti dan Jasa Pernikahan Asing. Juga meIalui Yayasan sejenis melakukan bisnis permebelan, pencetakan, dan perkreditan rakyat. disampaikan oleh Pilzer (2005)para pebisnis Kristen harus mau belajar dengan kesalahan untuk menuju kesuksesan. Inovasi dan kreativitas harus diupayakan oleh pengusaha Kristen untuk menghasilkan produk yang bernilai 
jual Tinggi. Perusahaan rekaman Sony belajar dari kesalahan terhadap perkembangan dunia rekam dari pisa kaset menuju rekaman digital (Suroso, p. 30).

McGraith dan Mac Millan dalam Rhenald Kasali (2010) menyebutkan tujuh karakter yang harus dimiliki oleh setiap calon wirausaha yaitu: action oriented, berfikir simpel, selalu mencari peluang baru, mengejar peluang dengan disiplin tinggi, hanya mengambil peluang yang terbaik, fokus pada eksekusi, serta memfokuskan energi setiap orang pada bisnis yang digeluti. Seorang wirausaha juga harus mempunyai kemampuan untuk bersahabat dengan ketidakpastian (Supriyanto, 2012).

\section{Implementasi}

Implementasi social entrepreneurship berbasis ekonomi kreatif masih memiliki beberapa kelemahan diantaranya: masih banyak pengrajin yang berusaha sendiri-sendiri dalam mengelola usahanya dan koordinasi dengan pemerintah daerah masih belum maksimal. Komunitas pengrajin belum berjalan maksimal dalam meningkatkan kualitas usaha pengrajin sehingga terkesan mereka (pengrajin) saling bersaing sesama pengrajin sendiri. Ide kreatif dan terobosan inovasi untuk mengembangkan produk sudah cukup baik, maka perlu didukung oleh pemerintah. Pemerintah harus dilibatkan dalam mendukung usaha mereka khususnya dalam mengeluarkan aturan yang berpihak pada pengrajin. Minimnya generasi muda meneruskan usaha kerajinan oleh keluarga menjadikan jumlah pengrajin berkurang. Selain itu, tingkat pendidikan yang relatif rendah dan usia yang tidak lagi produktif dapat menjadi kendala dalam implementasi social entrepreneurship. Konsep kewirausaha- 
an sosial yang akan dijalankan harus berorientasi pada permasalahan sosial yang dihadapi masyarakat, dengan mengedepankan pemberdayaan dan kerjasama dengan berbagai pihak. Kegiatan usaha sosial yang dilakukan harus berdampak pada perubahan pada masyarakat untuk jangka panjangnya (Rahadi, 2018).

Pola dan program pendidikan mampu menumbuhkan kompetensi dan mengembangkan karakteristik kewirausahaaan sejak dini hingga penguatan pada proses diserta bereksperimen menjadi salah satu fokus utama dalam memupuk kebijaksanaan berpikir dan bertindak yang dibutuhkan kewirausahaan (Juliawati, 2018).

Modal dasar yang dibutuhkan untuk menjadi wirausahawan sosial adalah lebih kepada komitmen untuk membuat perubahan sosial berdasarkan tujuan mulia. Penguaha sosial harus memiliki strategi berdaarkan kekuatan sosial untuk menyebarkan pengaruhnya, penggunaan media sosial akan membantu organisasi maupun individu untuk menyebarkan permaalahan yang dialami masyarakat. Untuk itu pengusaha sosial berfokus pada pengalaman yang dialami masyarakat, sehingga sangat perlu untuk menjalin komunikasi serta mambangun empati melalui peritiwa yang dialami oleh masyarakat (Saragih, 2017).

Kebijakan lain yang telah dilakukan oleh pemerintah dalam rangka pengembangan kewirausahaan adalah melalui kemudahan akses permodalan bagi usaha kecil dan pelatihan serta pendampingan melaui program Kredit Usaha Rakyat yang ditujukan bagi usaha kecil yang feasible tetapi tidak bankable dan program PNPM baik perdesaan maupun perkotaan, di samping melakukan pendampingan dan pelatih- 
an (Badriah, 2014).

Berbagai elemen keberagamaan (teologi, intelektual, pengalaman dan ritual) tidak berdiri sendiri, melainkan berada dalam barisan formasi teologis, yakni tatanan rancang bangun unsur-unsur pembentuk teologi, mulai dari aspek kognisi, internalisasi sampai objektivikasinya dalam lingkungan bisnis. Hasil fermentasi unsur-unsur formasi teologis ini akan melahirkan spirit wirausaha, sehingga secara eksternal ia akan bertransformasi secara intrapersonal, interpersonal, dan transpersonal. Besaran spirit wirausaha seseorang bergantung pada kadar senyawa dan valensi unsur-unsur teologi yang dilakukannya (Jalil, 2015).

\section{KESIMPULAN}

Kewirausahaan adalah sebuah kenisayaan bagi gereja di era digital di mana kesejahteraan jemaat adalah prioritas utama, lahir maupun batin. Meskipun perkembangan kewirausahaan dalam gereja masih sangat minim. Disebabkan berbagai faktor, baik konsep teologi, keinginan berwirausaha jemaat dan menganggap berwirausaha tidak boleh dicampur dengan kehidupan rohani. Dengan perkembangan teknologi yang pesat, gereja seyogyanya cepat menanggapi perubahan zaman. Dengan memanfatkan teknologi dengan tepat untuk kemaslahatan jemaat. Kristus adalah kepala jemaat, dengan meneladani sikap dan perilaku Yesus dalam dunia. Hubungan Kristus dan jemaat. Tuntutan di era digital gereja memanfaatkan pemberitaan Injil secara online. Serta membangun kewirausahaan secara online dari berbagai segi kehidupan jemaat. 


\section{DAFTAR PUSTAKA}

Afandi, Y. (2018). Gereja Dan Pengaruh Teknologi Informasi "Digital Ecclesiology." FIDEl: Jurnal Teologi Sistematika Dan Praktika, 1(2), 270-283. https://doi.org/10.34081/fidei.v1i2.12

Andriono, T. (2017). Bagaimana Memanfaatkan Teknologi Informasi dan Komunikasi.

Badriah, L. S. (2014). Pengembangan Inovasi dan Kewirausahaan Sebagai Upaya Menghadapi Era Masyarakat Ekonomi ASEAN 2015. Sustainable Competitive Advantage (SCA), 21-33. Retrieved from http://jp.feb.unsoed.ac.id/index.php/sca-1/article/view/655

Budiyanto, H. (Universitas M. M. (2017). Program Pengembangan Kewirausahaan Dalam Bentuk Inkubator Bisnis Di Perguruan Tinggi Bagi Mahasiswa Pemilik Usaha Pemula. Seminar Nasional Sistem Informasi (Senasif) 2017, (September), 385-394. Retrieved from https://seminar.unmer.ac.id/index.php/senasif/2017/paper/view/33/39

Buono, G. H. (2017). Keterlibatan Gereja dalam Latihan Kewirausahaan Pemuda. Retrieved April 7, 2019, from http:// gkjwtunglur.blogspot.co.id/2017/03/basar-pemuda-gkjw-jemaattunglur.htm

DBS. (2017). Mendorong Wirausaha Baru di Era Digital. Retrieved May 27, 2019, from www.dbs.com website: https://www.dbs.com/spark/ index/id_id/dbs-yes-asset/files/(Riset 2) Mendorong Wirausaha Baru di Era Digital.pdf

Harjono, B. (2011). Bahan Ajar Kewirausahaan. STT INTI.

Hartono, H. (2018). Mengaktualisasikan Amanat Agung Matius 28 : 19-20 dalam Konteks Era Digital. KURIOS (Jurnal Teologi Dan Pendidikan Agama Kristen), 4(2), 19-20. Retrieved from www.sttpb.ac.id/ejournal/index.php/kurios

Haryani, S. (2017). Pengaruh Lingkungan Kewirausahaan Terhadap Pengembangan Wirausaha Di Kabupaten Sleman. EKUITAS (Jurnal Ekonomi Dan Keuangan), 1(1), 24. https://doi.org/10.24034/ j25485024.y2017.v1.i1.1841

Jalil, A. (2015). Teologi Wirausaha. ISLAMICA: Jurnal Studi Keislaman, 6 (2), 203. https://doi.org/10.15642/islamica.2012.6.2.203-214

Julianto, Si. (2017). Kewirausahaan Jemaat: Sebuah Alternatif Berteologi. WASKITA, Jurnal Studi Agama Dan Masyarakat, 151183. 
Juliawati, N. (2018). Membangun Kewirausahaan: antara Digital Ekonomy dan Human Economy. Bandung.

Marbun, D. P., \& Kaihatu, V. A. M. (2016). Pemahaman Uang dan Usaha Menuju Kewirausahaan. Prosiding Seminar Nasional Psikologi UMG. Tangerang Selatan: Universitas Pembangunan Jaya.

Nababan, T. S. (2011). Gereja dan Kesejahteraan Warga Dalam Perspektif Ekonomi Kerakyatan. MPRA Paper No. 49096, 1-10.

Rahadi, D. R. (2018). Analisis Sektor Usaha Kecil \& Menengah Menjadi Model Kewirausahaan Sosial Berbasis Ekonomi Kreatif. Jurnal Manajemen Dan Bisnis Indonesia, 4(2), 159-173. https:// doi.org/10.31843/jmbi.v4i2.115

Rini, A. D. (2016). Relevansi Sustainability, Accountability, Transparency Program Entrepreneurial University terhadap Sikap Komunitas Gereja. Jurnal Akuntansi Multiparadigma, 6(3), 1-14. https:// doi.org/10.18202/jamal.2015.12.6035

Rizky, D. A. (2018). Studi Perbandingan Gaya Kepemimpinan Kerja Tim, Kultur Organisasi, dan Intensi Berwirausaha pada Pegawai Lembaga Pemasyarakatan A, B dan C. Journal of Government and Civil Society, 1(1), 1. https://doi.org/10.31000/jgcs.v1i1.275

Rosmiati, R., Junias, D. T. S., \& Munawar, M. (2015). Sikap, Motivasi, Dan Minat Berwirausaha Mahasiswa. Jurnal Manajemen Dan Kewirausahaan (Journal of Management and Entrepreneurship), 17 (1), 21-30. https://doi.org/10.9744/jmk.17.1.21-30

Saragih, I. (2017). MEMBANGUN USAHA KREATIF, INOVATIF DAN BERMANFAAT MELALUI PENERAPAN KEWIRAUSAHAAN SOSIAL Rintan. Jurnal Kewiraushaan, 3(2), 50-58.

Sianturi, R. P. (2014). Komunitas Virtual Kristen: Era Baru Eklesia dalam Konteks Virtual dan Kontribusinya bagi Kebangsaan Beragama di Indonesia. Gema Teologi, 38(1), 97.

Sitompul, R. P. (2017). Pelayanan Pemuda di Era Teknologi Digital. Jurnal Antusias, 5(1).

Sumbung, G., Suman, A., Kliwon, H., \& Paulus, K. (2012). Peran Gereja Dalam Peningkatan Ekonomi Masyarakat Di Tomohon Sulawesi Utara. Wacana, 15(4). 
Supriyanto, I. G. (2012). Pengaruh Persepsi mahasiswa tentang Pendidikan Kewirausahaan Terhadap Kepercayaan Diri dan Motivasi Mahasiswa Program Studi Akuntansi (Studi Kasus pada Fakultas Ekonomi Universitas Widyatama). Perkembangan Peran Akuntansi Dalam Bisnis Yang Profesional. Bandung: SNAB 2012.

Suwardana, H. (2017). Revolusi Industri 4.0 Berbasis Revolusi Mental. ATI UNIK 2017, Vol . 1 No. 2 Hal 102-110, 1(2), 102-110. https:// doi.org/http://ojs.unik-kediri.ac.id/index.php/jatiunik/article/view/117/0

Tafonao, T. (2019). KEPRIBADIAN GURU KRISTEN DALAM PERSPEKTIF 1 TIMOTIUS 4: 11-16. Evangelikal: Jurnal Teologi Injili Dan Pembinaan Warga Jemaat, 3, 62-81.

Tari, E. (2018). Teologi Tongkonan: Berteologi dalam Konteks Budaya Toraja. Epigraphe: Jurnal Teologi Dan Pelayanan Kristen, 2(2), 93102.

Tomatala, Y. (2010). Spiritual Enterpreneurship Anda Juga Bisa Menjadi Enterpreneur Rohani. Jakarta: YT Leadership Foundation.

Zimmerer, T. W., Scarborough, N. M., \& Wilson, D. (2008). Essentials of Enterpreneurship and Small Bussiness Management. New Jersey: Pearson Pretice Hall Inc. 